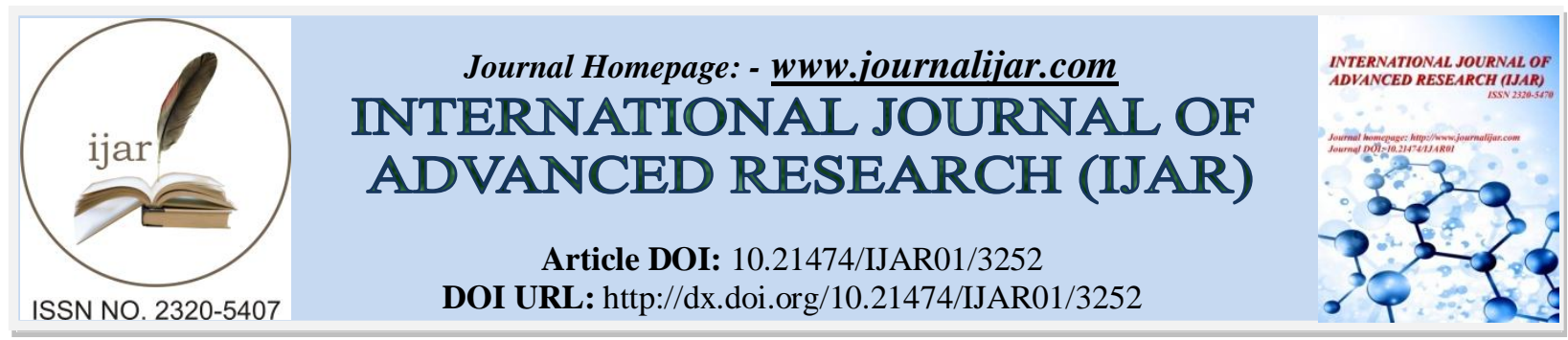

RESEARCH ARTICLE

\title{
HEPATITIS E VIRUS IN RENAL TRANSPLANT RECIPIENTS.
}

\section{Malak A Aboukhatwa ${ }^{1}$, Nesrine F Hanafi ${ }^{1}$, ${ }^{*}$ Sarah M Abdelhamid ${ }^{2}$, Yasmine S Naga ${ }^{3}$ and Sahar M Abdelfatah'.}

1. Department of Medical Microbiology \& Immunology, Faculty of Medicine, Alexandria University, Egypt.

2. Department of Microbiology \& Immunology, Faculty of Pharmacy, Damanhour University, Damanhour, Egypt.

3. Department of Internal Medicine; Faculty of Medicine, Alexandria University, Egypt.

\section{Manuscript Info}

Manuscript History

Received: 24 December 2016

Final Accepted: 23 January 2017

Published: February 2017

Key words:-

ELISA; Hepatitis E virus, Ig, Real Time

PCR, Viral Hepatitis

\begin{abstract}
Hepatitis $\mathrm{E}$ virus is claimed to represent the most frequent cause of acute hepatitis and jaundice all over the world. In 2008, HEV was reported possibly to be responsible for chronic infection in immunosuppressed patients such as organ transplant recipients. This study aims at detection of HEV RNA and HEV IgM and IgG antibodies in sera of renal transplant Egyptian patients compared to apparently healthy control group of matched age and sex. The present study was carried out on sixty renal transplant patients recruited from the Transplantation Unit at Alexandria Main University Hospital and sixty apparently healthy control subjects. Sera of all cases and controls have been subjected to Real Time PCR for detection of HEV RNA and qualitative ELISA determination of HEV IgM and IgG

Anti HEV IgG was positive in $56.7 \%$ of cases (34 out of 60 ) and in $75 \%$ of control subjects (45out of 60). HEV RNA was detected in 2 cases (3.3\%) among renal transplant recipients, while the sixty control subjects were all negative.

There is a high seroprevalance of HEV IgG among both patients and controls. The statistically insignificant lower prevelance among transplanted patients might be justified by intake of immunosuppressive drugs. Transplant recipients showed higher rate of HEV RNA positivity. The impact of immunosuppression on rate of viral clearance among such category of patients needs to be noted.
\end{abstract}

Copy Right, IJAR, 2017,. All rights reserved.

\section{Introduction:-}

Hepatitis E virus (HEV) is considered the main cause of enterically transmitted hepatitis globally, being accountable for more than $50 \%$ of the cases of acute hepatitis in endemic countries where the disease is transmitted through drinking water and causes serious epidemic outbreaks. (Pérez-Gracia et al. 2013).

HEV is mainly prevalent in tropical and subtropical regions with much lower prevalence in developed countries.(Kumar et al. 2013) HEV infection courses as an asymptomatic or a self-limiting symptomatic acute hepatitis, but fulminant hepatitis may happen, particularly in pregnant women or in people with an underlying liver disease.(Péron et al. 2007) However, in 2008 it has been shown that HEV imposes a problem to immunosuppressed patients such as solid-organ transplant recipients, and HIV patients. Chronicity rates have been reported to be higher with failure of $60 \%$ of transplant 
recipients to clear the HEV, (Halac et al. 2012) and the possibility in $10 \%$ to develop cirrhosis within a short period of time.(Colson et al. 2009; Gérolami et al. 2008; Kamar et al. 2011; Ollier et al. 2009) Researchers have reported that an antibody response to HEV may be absent in these immunosuppressed patients and recommended the trial for the detection of HEV RNA when serum liver tests are elevated over several months. (Gérolami et al. 2009) Other researchers noted that Chronic hepatitis $\mathrm{E}$ in renal transplant patients has been found to be associated with normal liver enzymes and a negative serological assay. (Gérolami et al. 2008)

This study aims at detection of HEV RNA and HEV IgM and IgG antibodies in sera of renal transplant Egyptian patients compared to apparently healthy control group of matched age and sex.

\section{Material \& Methods:-}

The present study was carried out on sixty renal transplant patients recruited from the Transplantation Unit at Alexandria Main University Hospital during the period from 1/12/2013 to 28/3/2015. Sixty apparently healthy control subjects have been enrolled in the study with matched age and sex.

Serum samples collected from cases and control subjects were subjected to: RNA extraction using ISOLATEII RNA Mini Kit (Bioline, U.K) and amplification of HEV RNA by Real Time PCR technique using SensiFast SYBR NoROX One - Step kit (UK) and a light cycler (Applied Biosystem, One Step)

In the present study a primer set on the ORF2 HEV genome was chosen in a highly conserved region, (GenBank accession no. X98292, strain hev037)(Orrù et al. 2004)

Primers used for HEV RNA amplification were 5'- GCGGTGGTTTCTGGGG -3' and 5' -TTCCCC AAC CAA CCT$3^{\prime}$

ELISA technique was employed for the detection of Specific IgM (DRG® International Inc. HEV IgM assays. USA) and IgG (DRG® International Inc. HEV IgG assays. USA) to HEV (Rostamzadeh Khameneh Z et al. 2011)

Aspartate transaminase (AST) and alanine transaminase (ALT) levels were measured for both transplant patients and healthy controls.

\section{Results:-}

The age of renal transplant cases enrolled in the study ranged from 28-53 with a mean of $38.48 \pm 6.41$. Sex distribution showed $40(66.6 \%)$ males and $20(33.3 \%)$ females with no statistically significant difference when compared to controls. The graft age in the transplant group ranged from 2-9 years with the mean of 6,225 $\pm 2,638$. Both cases and controls' sera were negative to anti HEV IgM . Table 1 shows distribution of cases and controls according to IgG posititvity. HEV IgG positivity prevelance was higher among control group compared to cases with no statistically significant diffrence. $(\mathrm{p}=0.098)$

Transplant cases showed two positive HEV RNA cases by Real Time PCR (3.4\%) while control subjects were all negative. There was no statistical significant difference $(\mathrm{P}=0.494)$ (Table 2$)$. IgG response was positively detectable in only one of the two PCR positive HEV cases.

In a comparison set between cases and control; the level of AST ranged between 12-65 IU/L with the mean of 24.20 $\pm 10.32 \mathrm{IU} / \mathrm{L}$ for cases and 15-28 IU/L with the mean of $21.42 \pm 3.75 \mathrm{IU} / \mathrm{L}$ for control. There was no statistical significant difference between them. $(\mathrm{P}=0.311)$.

In cases ALT level ranged between 15-85 IU/L with the mean of $27.38 \pm 11.58 \mathrm{IU} / \mathrm{L}$ and 16-34 IU/l with the mean of $23.05 \pm 3.90 \mathrm{IU} / \mathrm{L}$ for control, There was a statistically significant difference between cases and control regarding ALT. $(\mathrm{P}=0.017)$ (Table 3).

Distribution of renal transplant cases with positive HEV RNA and transplant cases with negative HEV RNA according to liver enzyme level, AST showed a mean level of $62.50 \pm 3.54 \mathrm{IU} / \mathrm{L}$ for positive cases, and $22.18 \pm$ 5.34IU/L for negative cases. There was a statistically significant difference between PCR positive and negative cases $(\mathrm{P}=0.018)$. 
ALT showed a mean level of 70.0 $\pm 21.21 \mathrm{IU} / \mathrm{L}$ for positive cases, and 25.13 $\pm 5.09 \mathrm{IU} / \mathrm{L}$ for negative cases. There was an also statistically significant difference between HEV RNA positive and negative cases regarding ALT level. $(\mathrm{P}=0.018)$.

Comparing transplant cases with positive and negative IgG according to liver enzyme level, AST showed mean level of $23.83 \pm 9.08 \mathrm{IU} / \mathrm{L}$ for positive cases, and a mean level of $24.71 \pm 12.07 \mathrm{IU} / \mathrm{L}$ for negative cases, with no statistically significant difference $(\mathrm{P}=0.891)$. While ALT showed a mean level of $27.65 \pm 13.53$ IU/L for positive cases, and 27.0 \pm 8.67IU/L for negative cases. There was also no statistically significant difference $(\mathrm{P}=0.816)$.

\section{Discussion:-}

Hepatitis E virus (HEV) is responsible for more than $50 \%$ of the cases of acute hepatitis in endemic countries, and is considered to be an emerging infectious disease. (Pérez-Gracia et al. 2013)

To our knowledge this is the first cross sectional study to consider Real Time PCR for HEV in addition to serological tests in investigating the prevalence of HEV among renal transplant recipients in Egypt.

The present study was conducted on sixty serum samples collected from renal transplant patients; with sixty apparently healthy age and sex matched control subjects.

Most of the studies conducted for the detection of HEV RNA in serum samples selected the real time PCR as a reliable method for the assay. In a French study, Kamar et al, studied serum samples of 160 kidney transplant recipients and revealed HEV RNA in $7 \%$ of renal transplant recipients denoting the high endemicity of $\mathrm{HEV}$ infection in southern France.(Kamar et al. 2008a) In another study, he (Kamar et al), identified 6.5\% positive cases of 217 patients , tested for serum HEV RNA receiving different types of grafts .(Kamar et al. 2008b)

In agreement with the previous data, our detection of HEV RNA by real time PCR results showed two positive cases $(3.4 \%)$ in renal transplant cases while all control subjects were negative, which reflects a higher rate of detection of HEV RNA among transplanted patients compared to normal population. This observation can be justified by longer duration of viremia among immunosuppressed and less rate of clearance of the virus evidenced by many researchers.(Krain et al. 2014)

In a similar study, Legrand-Abravanel et al. detected HEV RNA using real time PCR. in $8 \%$ of 700 kidney transplant recipients (Legrand-Abravanel et al. 2011)

Serological assessment has been considered a gold standard for evidencing infection by HEV. Estimation of the $\mathrm{IgG}$ level in serum has been interpreted by many scientists to determine the state of infection whether past, acute or chronic infection.(Lin et al. 2000)

Our results of $\mathrm{HEV}$ antibodies of IgG in renal transplant cases were positive in $56.7 \%$ (including the two positive PCR cases) and negative in $43.3 \%$. While the results in control subjects were 45 cases $\operatorname{IgG}$ positive and 15 cases IgG negative.

The negative results could be related to either the immunosuppressive drugs which may lead to a loss of antibodies or a possible weak antibody response.

In 2011 Rostamzadeh Khameneh et al. reported 28 subjects (30.8\%) out of 91 kidney transplant patients were seropositive for anti-HEV IgG.(Rostamzadeh Khameneh Z et al. 2011) Another study by Kamar, et al showed the prevalence of HEV IgG was $14.5 \%$ from 241 kidney recipients, and 10.4\% from 86 liver recipients. (Kamar et al. 2008b) Other researchers reported the seroprevalence of HEV in French renal transplant recipients to be $14.5 \%$, while its prevalence in blood donors in southwestern France, represented as the general population, was 16.6\%.(Mansuy et al. 2008)

In the present study the level of AST ranged between 12-65 IU/ml for cases and 15-28 IU/ml for control subjects. While, ALT level ranged between 15-85 IU/L for cases and 16-34 IU/L for controls. There was a statistically significant difference between cases and controls regarding ALT. $(\mathrm{P}=0.017)$. 
A similar association was also reported by Kamar et al who showed increase ALT levels from 13 to 156 IU/L (N =5-55), AST levels from 22 to $115 \mathrm{IU} / \mathrm{L}(\mathrm{N}=5-40)$ among renal transplant patient infected with HEV. (Kamar et al. 2011) Previous study by Kamar et al showed elevated ALT (15 to 200 IU/L) and AST level (25 to 110 IU/L) among renal transplant recipients infected with HEV.(Kamar et al. 2008a)

Confirming our results, Pas et al. studied 1,200 solid organ transplant recipients. Twelve HEV-infected patients had identified peak ALT level, 301 IU/L (81-909) and peak AST level, 172 IU/L (66-1016).(Pas et al. 2012)

In our study a comparison between transplant cases with positive $\operatorname{IgG}$ and transplant cases with negative $\operatorname{IgG}$ according to liver enzyme level, AST showed a mean level of $23.83 \pm 9.08 \mathrm{IU} / \mathrm{L}$ for positive cases, and $24.71 \pm$ 12.07 IU/L for negative cases. ALT showed a mean level of $27.65 \pm 13.53 \mathrm{IU} / \mathrm{L}$ for positive cases, and $27.0 \pm$ 8.67IU/L for negative cases.

A similar association was also reported by Rostamzadeh Khameneh et al. In a comparison of patients' characteristics between the seropositive and seronegative groups for anti-HEV IgG, the ALT level ranged from 27-262 IU/L. The mean AST level was $51.4 \pm 18.4 \mathrm{IU} / \mathrm{L}$. The mean ALT level was 1.71 times the normal values. Fifty patients (54.9\%) had normal ALT levels, but 41 patients (45.1\%) had elevated ALT levels. (Rostamzadeh Khameneh Z et al. 2011)

Our results confirm previous data reporting a high prevalence of HEV infection among Egyptian population. Furthermore, we agree with other researches that renal transplant recipients exhibited a higher rate of positivity for HEV RNA versus healthy control. Considering the small number of positive cases it was not possible to judge the possibility of HEV persistence.

The lower HEV IgG rates in transplant patients- although the difference was statistically non-significant - may be safely attributed to the known depression of immune response in such patients.

Table (1): Comparison between cases and controls according to seropositivity for HEV IgG.

\begin{tabular}{|c|c|c|c|c|c|c|}
\hline & \multicolumn{2}{|c|}{ Cases $(n=60)$} & \multicolumn{2}{|c|}{ Control $(\mathrm{n}=60)$} & \multirow[t]{2}{*}{$\chi^{2}$} & \multirow[t]{2}{*}{${ }^{\mathrm{FE}} \mathbf{p}$} \\
\hline & No & $\%$ & No & $\%$ & & \\
\hline \multicolumn{7}{|l|}{ Ig G } \\
\hline Positive & 34 & 56,7 & 45 & 75 & \multirow[t]{2}{*}{2739} & \multirow[t]{2}{*}{0.098} \\
\hline Negative & 26 & 43.3 & 15 & 25 & & \\
\hline
\end{tabular}

Table (2): Distribution of the renal transplant cases and control according to positivity for HEV RNA.

\begin{tabular}{|c|c|c|c|c|c|c|c|c|}
\hline & \multicolumn{2}{|c|}{ Cases $(n=60)$} & \multicolumn{2}{|c|}{ Control $(n=60)$} & \multirow[t]{2}{*}{$\chi^{2}$} & \multirow[t]{2}{*}{${ }^{\mathrm{FE}} \mathbf{p}$} & \multicolumn{2}{|c|}{ Total $(n=120)$} \\
\hline & No & $\%$ & No & $\%$ & & & No. & $\%$ \\
\hline PCR & & & & & & & & \\
\hline Positive & 2 & 3.4 & 0 & 0.0 & 2.051 & 0.494 & 2 & 1.7 \\
\hline Negative & 38 & 96.6 & 60 & 100.0 & & & 118 & 98.3 \\
\hline
\end{tabular}

$\chi^{2}$ : Chi square test

FE: Fisher Exact

Table (3): Distribution of the renal transplant cases and control according to liver enzymes.

\begin{tabular}{|c|c|c|c|c|c|}
\hline & Cases $(n=60)$ & Control $(n=60)$ & $\mathbf{Z}$ & $\mathbf{p}$ & Total $(n=120)$ \\
\hline \multicolumn{6}{|l|}{ AST IU/L } \\
\hline Min.- Max. & $12.0-65.0$ & $15.0-28.0$ & \multirow[t]{3}{*}{1.014} & \multirow[t]{3}{*}{0.311} & $12.0-65.0$ \\
\hline Mean \pm SD. & $24.20 \pm 10.32$ & $21.42 \pm 3.75$ & & & $22.81 \pm 7.84$ \\
\hline Median & 23.0 & 21.50 & & & 23.0 \\
\hline \multicolumn{6}{|l|}{ ALT IU/L } \\
\hline Min.- Max. & $15.0-85.0$ & $16.0-34.0$ & \multirow[t]{3}{*}{$2.379^{*}$} & \multirow[t]{3}{*}{$0.017^{*}$} & $15.0-85.0$ \\
\hline Mean \pm SD. & $27.38 \pm 11.58$ & $23.05 \pm 3.90$ & & & $25.21 \pm 8.86$ \\
\hline Median & 26.0 & 22.50 & & & 23.50 \\
\hline
\end{tabular}

Z: Z for Mann Whitney test

*: Statistically significant at $\mathrm{p} \leq 0.05$ 


\section{References:-}

1. Colson, P., Kaba, M., Moreau, J. and Brouqui, P. (2009): Hepatitis E in an HIV-infected patient. J. Clin. Virol., 45(4), 269-271.

2. Gérolami, R., Moal, V. and Colson, P. (2008): Chronic hepatitis E with cirrhosis in a kidney-transplant recipient. N. Engl. J. Med., 358(8), 859-60.

3. Gérolami, R., Moal, V., Picard, C. and Colson, P. (2009): Hepatitis E virus as an emerging cause of chronic liver disease in organ transplant recipients. J. Hepatol., 50(3), 622-624.

4. Halac, U., Béland, K., Lapierre, P., Patey, N., Ward, P., Brassard, J., Houde, A. and Alvarez, F. (2012): Cirrhosis due to chronic hepatitis E infection in a child post-bone marrow transplant. J. Pediatr., 160(5), 8714.e1.

5. Kamar, N., Garrouste, C., Haagsma, E. B., Garrigue, V., Pischke, S., Chauvet, C., Dumortier, J., Cannesson, A., Cassuto-Viguier, E., Thervet, E., et al. (2011): Factors associated with chronic hepatitis in patients with hepatitis E virus infection who have received solid organ transplants. Gastroenterology, 140(5), 1481-9.

6. Kamar, N., Mansuy, J.-M., Cointault, O., Selves, J., Abravanel, F., Danjoux, M., Otal, P., Esposito, L., Durand, D., Izopet, J. et al. (2008a): Hepatitis E Virus-Related Cirrhosis in Kidney-and Kidney--Pancreas-Transplant Recipients. Am. J. Transplant., 8(8), 1744-1748.

7. Kamar, N., Selves, J., Mansuy, J.-M., Ouezzani, L., Péron, J.-M., Guitard, J., Cointault, O., Esposito, L., Abravanel, F., Danjoux, et al. (2008b): Hepatitis E virus and chronic hepatitis in organ-transplant recipients. N. Engl. J. Med., 358(8), 811-7.

8. Krain, L. J., Nelson, K. E. and Labrique, A. B. (2014): Host immune status and response to hepatitis E virus infection. Clin. Microbiol. Rev., 27(1), 139-165.

9. Kumar, S., Subhadra, S., Singh, B. and Panda, B. K. (2013): Hepatitis E virus: the current scenario. Int. J. Infect. Dis., 17(4), e228-33.

10. Legrand-Abravanel, F., Kamar, N., Sandres-Saune, K., Lhomme, S., Mansuy, J.-M., Muscari, F., Sallusto, F., Rostaing, L. and Izopet, J. (2011): Hepatitis E virus infection without reactivation in solid-organ transplant recipients, France. Emerg. Infect. Dis., 17(1), 30-39.

11. Lin, C.-C., Wu, J.-C., Chang, T.-T., Chang, W.-Y., Yu, M.-L., Tam, A. W., Wang, S.-C., Huang, Y.-H., Chang, F.-Y. and Lee, S.-D. (2000): Diagnostic value of immunoglobulin G (IgG) and IgM anti-hepatitis E virus (HEV) tests based on HEV RNA in an area where hepatitis E is not endemic. J. Clin. Microbiol., 38(11), 39153918.

12. Mansuy, J. M., Legrand-Abravanel, F., Calot, J. P., Peron, J. M., Alric, L., Agudo, S., Rech, H., Destruel, F. and Izopet, J. (2008): High prevalence of anti-hepatitis E virus antibodies in blood donors from South West France. J. Med. Virol., 80(2), 289-293.

13. Ollier, L., Tieulie, N., Sanderson, F., Heudier, P., Giordanengo, V., Fuzibet, J.-G. and Nicand, E. (2009): Chronic hepatitis after hepatitis $\mathrm{E}$ virus infection in a patient with non-Hodgkin lymphoma taking rituximab. Ann. Intern. Med., 150(6), 430-1.

14. Orrù, G., Masia, G., Orrù, G., Romanò, L., Piras, V. and Coppola, R. C. (2004): Detection and quantitation of hepatitis E virus in human faeces by real-time quantitative PCR. J. Virol. Methods, 118(2), 77-82.

15. Pas, S. D., de Man, R. A., Mulders, C., Balk, A. H., van Hal, P. T., Weimar, W., Koopmans, M. P., Osterhaus, A. D. and van der Eijk, A. A. (2012): Hepatitis E virus infection among solid organ transplant recipients, the Netherlands. Emerg Infect Dis, 18(5), 869-872.

16. Pérez-Gracia, M. T., Mateos Lindemann, M. L. and Caridad Montalvo Villalba, M. (2013): Hepatitis E: current status. Rev. Med. Virol., 23(6), 384-98.

17. Péron, J. M., Bureau, C., Poirson, H., Mansuy, J. M., Alric, L., Selves, J., Dupuis, E., Izopet, J. and Vinel, J. P. (2007): Fulminant liver failure from acute autochthonous hepatitis E in France: description of seven patients with acute hepatitis E and encephalopathy. J. Viral Hepat., 14(5), 298-303.

18. Rostamzadeh Khameneh Z, Sepehrvand N, Masudi S. (2011): Seroprevalence of hepatitis E among Iranian renal transplant recipients. Hepat. Mon., 2011(8), 646-651. 